\title{
THE EFFECT OF CARBON AND POLYPROPYLENE FIBERS ON THERMAL SHOCK RESISTANCE OF THE REFRACTORY CASTABLE
}

\author{
Valentin ANTONOVIČa ${ }^{\mathrm{a}}$, Jerzy WITEK ${ }^{\mathrm{b}}$, Romualdas MAČIULAITIS ${ }^{\mathrm{c}}$, Renata BORIS ${ }^{\mathrm{a}}$, \\ Rimvydas STONYS ${ }^{a}$ \\ ${ }^{a}$ Scientific Institute of Thermal Insulation, Vilnius Gediminas Technical University, \\ Linkmenu g. 28, 08217 Vilnius, Lithuania \\ ${ }^{b}$ Institute of Ceramics and Building Materials, Refractory Materials Division, \\ Toszecka str. 99, 44-100 Gliwice, Poland \\ ${ }^{c}$ Vilnius Gediminas Technical University, Saulètekio al. 11, 10223 Vilnius, Lithuania
}

Received 28 Oct 2016; accepted 01 Feb 2017

\begin{abstract}
This work investigates medium cement refractory castable with additives of carbon and polypropylene fibers. The peculiarities of microstructure changes in the fiber and castable matrix contact zone, channel formation, and changes of cold crushing strength of fiber additives, which have a refractory castable matrix under temperature treatment, were investigated. The investigation results allowed to predict that using a mix of fibers more effective than using them individually. The influence of fiber additives on the mechanical characteristics and thermal shock resistance of the refractory castable with fiber additives was tested. It was found that the addition of carbon fiber has a positive impact on the thermal shock resistance of the investigated castable, which is confirmed by the results obtained by thermal cycling, as well as by the values calculated for thermal shock resistance $R_{4}$ and $R_{s t}$. In addition, the results of the investigation of thermal cycling show that the value of the thermal shock resistance was highest when a mixed fiber additive (CF+PP) was used.
\end{abstract}

Keywords: carbon fiber, polypropylene fiber, thermal shock resistance, refractory, castable.

\section{Introduction}

Refractory castable is widely used in structures of different heat equipment in the cement, iron and steel, petrochemical industries and others (Nishikawa 1984).

Calcium aluminate cements and special ultra-dispersive additives (such as microsilica and reactive alumina) and various deflocculants (plasticizers) are used in the production of refractory castables. Depending on the content of calcium aluminate cement, refractory castables are divided into: medium (MCC, 8-15\%), low (LCC, 4-8\%) and ultra low (ULCC, 1-3\%) cement content refractory castable (Wohrmeyer, Parr 2008).

Metal and organic fibers, which perform some specific functions, are commonly used in refractory castables (Nili, Afroughsabet 2010; Pemberton et al. 2011). Stainless steel fibers improve the mechanical properties of castable and its thermal shock resistance (TSR) by restraining crack propagation (Rouchka, Vutnau 2010; Samadi, Fard 2003; Wojsa et al. 2004). The limiting temperature of stainless steel fibers application is about $1100{ }^{\circ} \mathrm{C}$ under oxidation and normal conditions (Lau, Anson 2006). Organic fibers (polypropylene, polyamide and others) are required for dense and deflocculated castables to facilitate the removal of water vapors in drying and initial heating (Innocentini et al. 2002; Leung, Balendran 2002; Peret et al. 2003) because castables are prone to explosive spalling under rapid heating (Innocentini et al. 2003a, 2003b; Olivier, Fabien 2014). These fibers shrink at a temperature below $100{ }^{\circ} \mathrm{C}$ and dissolve at $\sim 150{ }^{\circ} \mathrm{C}$, when the temperature is further increased. Water vapor is removed from the castable via microchannels formed in its structure. According to Schacht (2004), the strength and porosity of castable does not change, when the content of the fiber additive in the dry castable mixture is below $0.5 \mathrm{wt} \%$.

Carbon fibers are widely used for dispersion reinforcement of conventional concrete in civil engineering to improve its mechanical properties and to prevent the formation of cracks due to deformation (Ferrari et al. 2013; Qazi et al. 2015; Tabatabaei et al. 2014; Valivonis, Skuturna 2007; Wang, Adeli 2014). In the refractory castables, such fibers are not used because their operating temperature does not exceed $300-400{ }^{\circ} \mathrm{C}$. Using these fibers in refractory castable may be of interest to researchers because of their possibility to reinforce castable 
at the drying stage, thus preventing cracking. This could later have a positive effect on thermal resistance properties of refractory castable.

It is well known that TSR is an important property, determining the performance of a refractory material under various service conditions (Antonovič et al. 2010; Miyaji et al. 2014; Mertke, Aneziris 2015; Ribeiro, Rodrigues 2010; Wojsa et al. 2013). To determine and forecast it, the values of thermal shock resistance $R, R_{1}, R_{4}$ and $R_{s t}$ are commonly used (Hasselman 1963, 1969; Kingery et al. 1979). The criterion $R_{4}$ is proposed to describe high-strength materials with smaller initial microcracks, while for low-strength materials with larger microcracks, the criterion $R_{s t}$ is used (Rodriguez et al. 2002; Schacht 2004). Some authors believe that, in some cases, using both of the above-mentioned criteria, $R_{4}$ and $R_{s t}$, is justified (Harmuth et al. 1996; Wojsa et al. 2004).

Note, that for practical purposes, various techniques of cycling heating and cooling the material samples are used to evaluate the TSR of refractory castable (Goberis 2003). In this case, the number of cycles preceding sample failure is calculated.

The behavior of materials under thermal shock conditions depends not only on their properties, but also on the nature of the shocks: sudden heating causes the development of microcracks, while sudden cooling is accompanied by stable growth (Larson, Hasselman 1975).

In order to identify the micro processes responsible for non-linear material behavior, a technique for the preparation of specimens was developed that allows microscopic investigation before and after crack propagation (Harmuth et al. 1996).

The paper determines the effect produced by carbon and polypropylene fiber additives, and their mixtures on TSR of MCC, when the thermal cycling method with sample cooling in water is employed. Some of the obtained data were compared with the values of thermal shock resistance determined by the criteria $R_{4}$ and $R_{s t}$.

\section{Materials and methods}

\subsection{Materials used}

Testing was performed with calcium aluminate cement (CAC) "Gorkal-70". Its chemical composition (mass \%) is as follows: $\mathrm{Al}_{2} \mathrm{O}_{3}-69-72 ; \mathrm{CaO}-28-29 ; \mathrm{SiO}_{2}<0.5$; $\mathrm{Fe}_{2} \mathrm{O}_{3}<0.5$. The main minerals are: $\mathrm{CA}\left(\mathrm{CaO} \cdot \mathrm{Al}_{2} \mathrm{O}_{3}\right)$ and $\mathrm{CA}_{2}\left(\mathrm{CaO} \cdot 2 \mathrm{Al}_{2} \mathrm{O}_{3}\right)$, the additional phases are: $\mathrm{C}_{12} \mathrm{~A}_{7}$ $\left(12 \mathrm{CaO} \cdot 7 \mathrm{Al}_{2} \mathrm{O}_{3}\right)$ and $\alpha-\mathrm{Al}_{2} \mathrm{O}_{3}$.

Filler made of CAC clinker "Gorkal 50". Its chemical composition (mass \%) is as follows: $\mathrm{Al}_{2} \mathrm{O}_{3}-$ 49-50; $\mathrm{CaO}-36-37 ; \mathrm{SiO}_{2}-3-4 ; \mathrm{Fe}_{2} \mathrm{O}_{3}-8-9$. The main minerals are $\mathrm{CA}$, the additional phases are: $\mathrm{CA}_{2}, \mathrm{C}_{4} \mathrm{AF}\left(4 \mathrm{CaO} \cdot \mathrm{Al}_{2} \mathrm{O}_{3} \cdot \mathrm{Fe}_{2} \mathrm{O}_{3}\right), \mathrm{C}_{12} \mathrm{~A}_{7}$ and $\mathrm{C}_{2} \mathrm{AS}$ $\left(2 \mathrm{CaO} \cdot \mathrm{Al}_{2} \mathrm{O}_{3} \cdot \mathrm{SiO}_{2}\right)$. CAC and calcium aluminate clinker filler produced at the enterprise "Górka Cement" (Poland). Calcium aluminate clinker filler particle size was $0.5-4 \mathrm{~mm}$. Dispersive aggregate (DA) obtained by grinding chamotte $\mathrm{BOS} 145\left(\mathrm{Al}_{2} \mathrm{O}_{3} \sim 38.0 \%\right)$ aggregate produced at the enterprise "Tabex Ozmo" (Poland) in the ring mill and screened through a $0.14 \mathrm{~mm}$ sieve. Microsilica (MS) RW-Fuller $\left(\mathrm{SiO}_{2}-96.1 \%\right)$ produced at the enterprise "RW Silicium GmbH" (Germany). Calcinated alumina (CA) CTC-20 $\left(\mathrm{Al}_{2} \mathrm{O}_{3}-99.7 \%\right)$ produced at the enterprise "Almatis" (Germany). Deflocculants, such as polycarboxylate ether Castament FS-20 supplied at the enterprise "BASF Construction Solutions GmbH" (Germany) and sodium tripolyphosphate $\left(\mathrm{Na}_{5} \mathrm{P}_{3} \mathrm{O}_{10}\right)$.

In the castable composition carbon fiber (CF) - BMH4 mark (C - 99.99\%) (Russia), and polypropylene fiber (PP) - produced at the Sika Group enterprise (Turkey) (Sika 2007), as well as the additive based on their mixture were used. The technical characteristics of the fibers are given in Table 1; their morphology is demonstrated in Figure 1.

Table 1. Technical characteristics of CF and PP fibers

\begin{tabular}{l|c|c}
\hline \multirow{2}{*}{\multicolumn{1}{c|}{ Properties }} & \multicolumn{2}{c}{ Fiber additives } \\
\cline { 2 - 3 } & $\mathrm{CF}$ & $\mathrm{PP}$ \\
\hline Length, mm & $5.0 \pm 1$ & $6.0 \pm 1$ \\
Diameter, $\mu \mathrm{m}$ & $6 \pm 1$ & $20 \pm 1$ \\
Density, g/cm ${ }^{3}$ & 1.71 & 0.91 \\
Young's modulus, GPa & $40-100$ & $6-9$ \\
Tensile strength, MPa & $500-1200$ & $300-440$ \\
Colour & black & natural \\
Temperature of use & max +450 & max +160 \\
(in the air), ${ }^{\circ} \mathrm{C}$ & & \\
\hline
\end{tabular}

a)

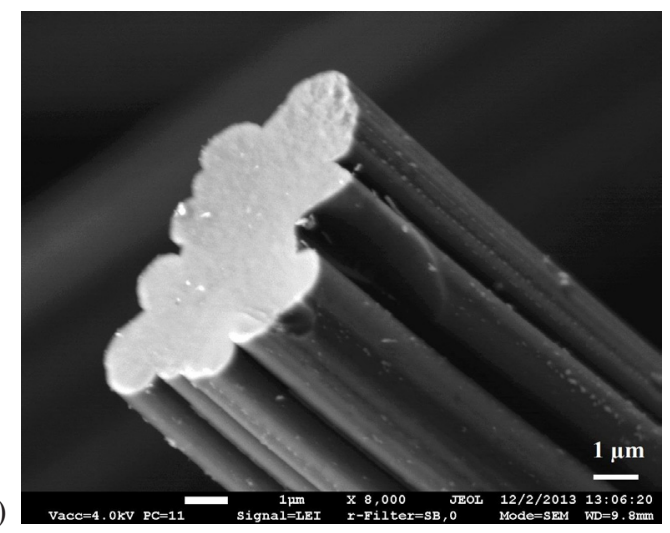

b)

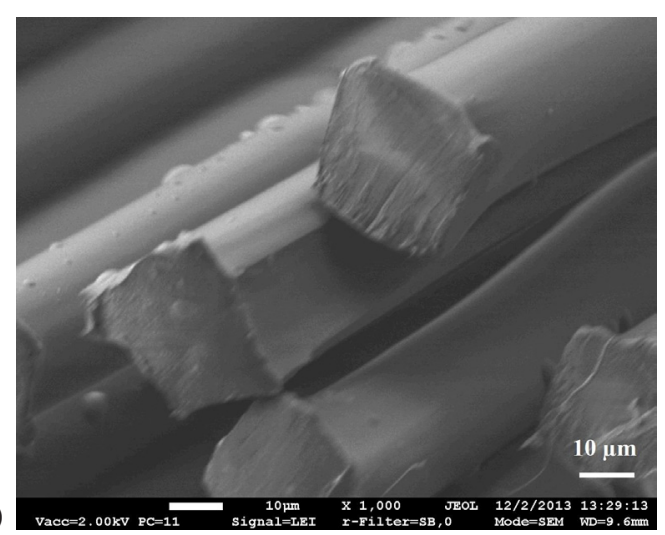

Fig. 1. Morphology 


\subsection{Specimen preparation}

Six kinds of MCC (see Table 2 for composition) were investigated. The control specimens of castable (B0) were prepared by dry mixing materials such as $\mathrm{CAC}$, microsilica, dispersed aggregate and clicker filler in the highspeed Eirich R02E mixer for 2 minutes. The dry mix obtained was mixed for 4 minutes in the Hobart mixer after adding the respective amount of water (more than 100\% of the dry material). The formation masses of refractory castable specimens, obtained in this way, were poured into $40 \times 40 \times 160 \mathrm{~mm} ; 25 \times 25 \times 150 \mathrm{~mm}$ and $70 \times 70 \times 70 \mathrm{~mm}$ forms, which were put in the 3401 RUMED (Rubrath Apparate $\mathrm{GmbH}$, Germany) climatic chamber and, then, the formed castable specimens were left for $72 \mathrm{~h}$ to harden. The temperature during the manufacture of the samples, and the temperature of the components being mixed, as well as the temperature in the climatic chamber was $20 \pm 1^{\circ} \mathrm{C}$.

The $\mathrm{B} 1$ and $\mathrm{B} 2$ specimens with $\mathrm{CF}$ additives, $\mathrm{B} 3$ and B4 with PP additives, as well as the B5 specimen with a mix additive $(\mathrm{CF}+\mathrm{PP})$ were prepared in a similar way as the B0 specimens. However, when making the B1-B5 specimens, the dry mix was mixed with the suitable amount of fibers.

Table 2. Mix proportion of the tested castables

\begin{tabular}{l|c|c|c|c|c|c}
\hline \multirow{2}{*}{ Materials } & \multicolumn{6}{|c}{ Castable composition, wt \% } \\
\cline { 2 - 7 } & B0 & B1 & B2 & B3 & B4 & B5 \\
\hline Clinker filler & 63 & 63 & 63 & 63 & 63 & 63 \\
DA & 15 & 15 & 15 & 15 & 15 & 15 \\
CAC & 12 & 12 & 12 & 12 & 12 & 12 \\
CA & 5 & 5 & 5 & 5 & 5 & 5 \\
MS & 5 & 5 & 5 & 5 & 5 & 5 \\
Deflocculants* & 0.2 & 0.2 & 0.2 & 0.2 & 0.2 & 0.2 \\
CF* & - & 0.01 & 0.02 & - & - & 0.02 \\
PP* & - & - & - & 0.02 & 0.04 & 0.04 \\
\hline Water* & \multicolumn{7}{|c}{5} \\
\hline
\end{tabular}

* denotes the content of the components exceeding $100 \%$ dry castable mix.

The principal technological scheme for the preparation of refractory castable specimens which were studied in this work are shown in Figure 2.

\subsection{Methods}

The consistency of freshly mixed castable was controlled using the Ball-in-Hand test (ASTM C860-15). Irrespective of the fiber used, the consistency obtained of all compositions of castables led to the correct "ball" which provided a good performance of castable.

Drying and heating of castable and binder were performed according to the methods recommended by the instruction of LST EN ISO 1927-5 (2013). Physical and mechanical properties were performed according to the methods recommended by the instruction of LST EN ISO 1927-6 (2013).

Cold crushing strength (CCS) was determined using the ALPHA 3-3000 S (Form Test Seidner and Co. GmbH, Germany) test machine.

The ultrasonic wave velocity was measured by the Pundit 7 (Instruments A/S, Germany) device using two $54-\mathrm{kHz}$ standard cylindrical transducers (transmitter and receiver). The measuring surface of the transducers was pressed against the samples at two strictly opposite points. Vaseline was used to insure a good contact. The ultrasonic wave velocity (UWV) in $\mathrm{m} / \mathrm{s}$ was calculated: $V_{U W V}=S / t$ ( $S$ is distance in meters; $t$ is time in seconds).

Thermal shock resistance of the refractory castable was determined according to the provisions of standard GOST 20910-90 (1991) for $70 \times 70 \times 70 \mathrm{~mm}$ samples, with the heating cycles $950{ }^{\circ} \mathrm{C}(40 \mathrm{~min})$, cooling in water (5 min) and air (10 min). The process was continued until a $20 \%$ loss of specimen volume was achieved.

The linear coefficient of thermal expansion was determined by the dilatometer Linseis L76 (Linseis Messgeraete $\mathrm{GmbH}$, Germany).

The values of thermal shock resistance were calculated by the equations:

$$
\begin{aligned}
& R_{4}=\frac{E \cdot \gamma_{w o f}}{\sigma_{f}^{2}} ; \\
& R_{s t}=\sqrt{\frac{\gamma_{w o f}}{E \cdot \alpha^{2}}},
\end{aligned}
$$

where: $\mathrm{E}$ is Young's modulus (GPa); $\gamma_{\text {wof }}$ is the work of fracture $\left(\mathrm{J} / \mathrm{m}^{2}\right) ; \sigma_{f}$ is bending strength (MPa); $\alpha$ is linear thermal expansion coefficient $\left(\mathrm{K}^{-1}\right)$.

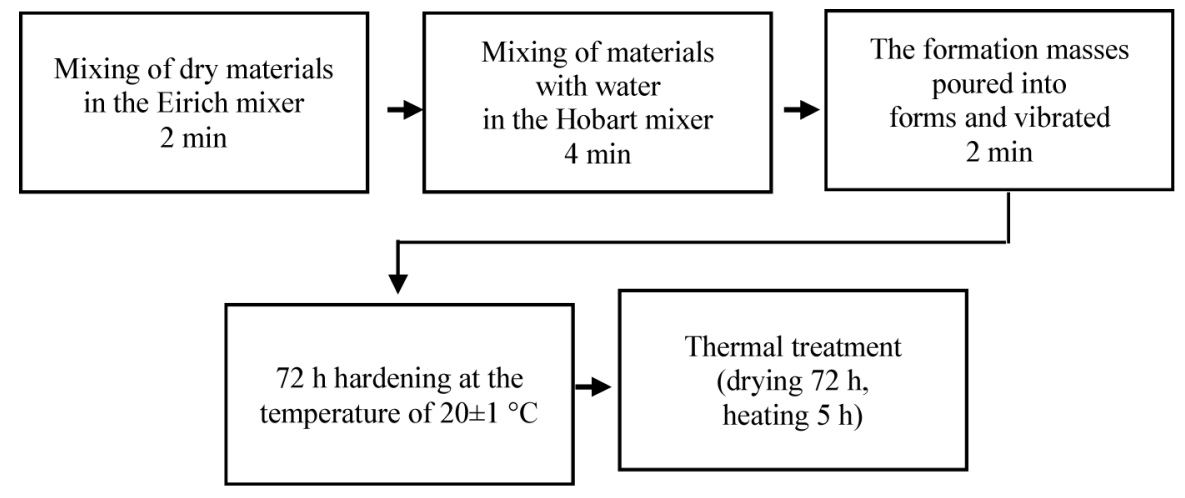

Fig. 2. The principal technological scheme for the preparation, hardening and thermal processing of refractory castable specimens 
The microstructure of the samples was examined by the scanning electron microscope (SEM) JSM-7600F (JEOL, Japan). The specimens were split and fastened to the specimen holders of the microscope so that the cleavage surface could be observed. Testing was performed at $10 \mathrm{kV}$ accelerating voltage, secondary electrons were used to form images.

The examined samples were covered with a layer of electricity conducting material, using device "QUORUM Q150R ES" (Quorum Technologies Ltd, Germany).

Work of fracture was found by the method of threepoint bending of a $25 \times 25 \times 150 \mathrm{~mm}$ beam with a notch, having a depth of $6.0 \mathrm{~mm}$ and width of $0.5 \mathrm{~mm}$, at a loading rate of $200 \mu \mathrm{m} / \mathrm{min}$, the correction of deformation determined by a measuring system and the ambient temperature of $+20 \pm 1{ }^{\circ} \mathrm{C}$.

The HMOR422 (NETZSCH GmbH, Germany) machine was used in testing for determining the deformation of samples by means of an extensometer. The work of fracture $\gamma_{w o f}$, was calculated from the equation:

$$
\gamma_{w o f}=\frac{\int_{0}^{x} F(d x)}{2 \cdot A_{p}},
$$

where: $F$ is force $(\mathrm{N}), A p$ is specimen cross-sectional area $\left(\mathrm{m}^{2}\right), \Delta \mathrm{x}$ is deformation $(\mathrm{m})$.

The amounts of fibers per unit volume (N/VC) and the mean distance between them (S) were calculated by Eqns (4) and (5) (Peret, Pandolfelli 2006).

$$
\begin{gathered}
\frac{N}{V C}=\frac{4 \cdot \rho}{\pi \cdot d^{2} \cdot L} ; \\
S=\sqrt[3]{\frac{V C}{N}}=\sqrt{\frac{\pi \cdot d^{2} \cdot L}{4 \cdot \rho}},
\end{gathered}
$$

where: $\rho$ is the volumetric fraction of fibers in the castable, $d$ and $L$ denote the fiber diameter and length (m).

The modulus $E$ was found from the expression:

$$
E=V_{U W V}^{2} \rho\left(\frac{(1+\mu)(1-2 \mu)}{1-\mu}\right),
$$

where: $V_{U W V}$ is ultrasonic wave velocity $(\mathrm{m} / \mathrm{s}), \rho$ is bulk density of castable $\left(\mathrm{kg} / \mathrm{m}^{3}\right), \mu$ is Poisson ratio equal to 0.17 for all compositions of castable.

The "STATISTICA 7" computer program was used for statistical processing of the experiment data (Sakalauskas 1998).

\section{Research results and discussion}

The TSR of MCC samples was determined by heating samples to a temperature of $950{ }^{\circ} \mathrm{C}$. Table 3 shows the apparent bulk density, bending strength, CCS, UVW, Young's modulus and linear thermal expansion coefficient results of samples from concretes B0 and B1,
Table 3. Properties of castable samples after heating at a temperature of $950{ }^{\circ} \mathrm{C}$

\begin{tabular}{l|c|c|c|c|c|c}
\hline \multirow{2}{*}{ Properties } & \multicolumn{6}{|c}{ Castable composition } \\
\cline { 2 - 7 } & B0 & B1 & B2 & B3 & B4 & B5 \\
\hline$\rho, \mathrm{kg} / \mathrm{m}^{3}$ & 2442 & 2460 & 2456 & 2450 & 2440 & 2456 \\
$\sigma_{f}, \mathrm{MPa}$ & 17.3 & 19.2 & 19 & 20.4 & 21.1 & 20.8 \\
$C C S, \mathrm{MPa}$ & 108.1 & 111.1 & 140.6 & 132.2 & 149.4 & 141.1 \\
$V_{U V W}, \mathrm{~m} / \mathrm{s}$ & 4830 & 4930 & 4950 & 4730 & 4730 & 4610 \\
$E, \mathrm{GPa}$ & 47.2 & 50.4 & 51.7 & 47.5 & 48.9 & 45.4 \\
\hline$\alpha, \mathrm{x} 10^{-6}\left(\mathrm{~K}^{-1}\right)$ & \multicolumn{6}{|c}{7.4} \\
\hline
\end{tabular}

B2, B3, B4, B5 with various amounts of different fiber additives after heating at $950{ }^{\circ} \mathrm{C}$.

The investigation results obtained in determining the CCS and bending strength of castable samples show that, due to the additives of CF, PP or a mix of fibers, castable CCS is higher by $\sim 38 \%$, and its bending strength is higher by $\sim 22 \%$ compared to those of the control composition of castable B0.

It should be noted that after heating at a temperature of $800{ }^{\circ} \mathrm{C}$ (for $5 \mathrm{~h}$ ) the additives $\mathrm{CF}$ and $\mathrm{PP}$ burn out (Figs 3 a, 3b).

A possible explanation of castable strength increase can be given by the analysis of the microstructure of castable in the contact areas with the burnt-out fiber. It can be observed that in the area of contact with CF (Fig. 4a) and PP (Fig. 4b), densified castable sample microzones have formed. This micro-compaction of the castable matrix structure apparently appeared during cement hydration and remained after fiber burnout.

Perhaps, water distribution in the contact areas between the fibers and cement material differs from the water distribution in all of the castable due to the hydrophobic properties of PP and CF. Cement hydration peculiarities in such conditions are possible reasons for microcompaction of the structure around the fiber.

The amounts of CF (Eqn (4)) in $1 \mathrm{~cm}^{3}$ of castable are 370 and 720 , while the distances between the fibers are equal to 3.0 and $2.4 \mathrm{~mm}$, for formulations of $\mathrm{B} 1$ and $\mathrm{B} 2$, respectively. The amounts of PP (Eqn (5)) in $1 \mathrm{~cm}^{3}$ of castable are 130 and 260, while the distances between the fibers are 3.4 and $4.2 \mathrm{~mm}$, respectively, for castable compositions B3 and B4. These results show that the number of micro-areas with a densified castable matrix is significant. It seems to have a positive effect on the strength characteristics of castable.

The data obtained in investigating TSR of castable samples after heating at $950{ }^{\circ} \mathrm{C}$ and cooling in water (given in Fig. 5) show that TSR of castable samples with the addition of carbon fibers is $20 \%$ higher than TSR of samples without this additive.

The addition of PP slightly reduces TSR of castable (only one cycle fewer than in the case of samples without the fiber additive). The highest TSR is achieved when a mix of fibers is used. It is difficult to ex- 
a)

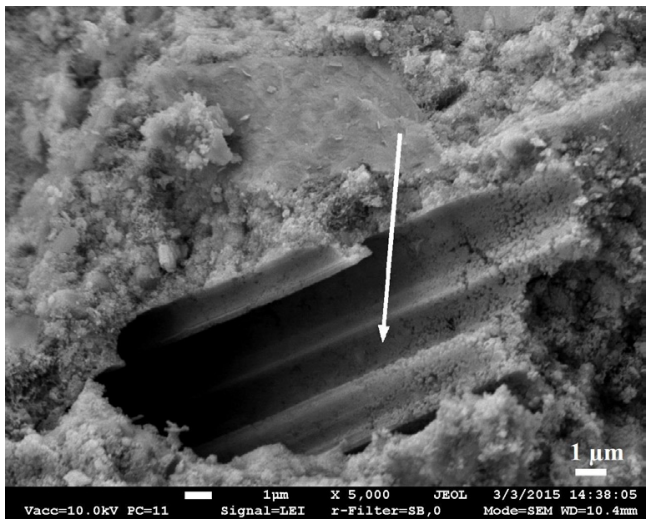

b)

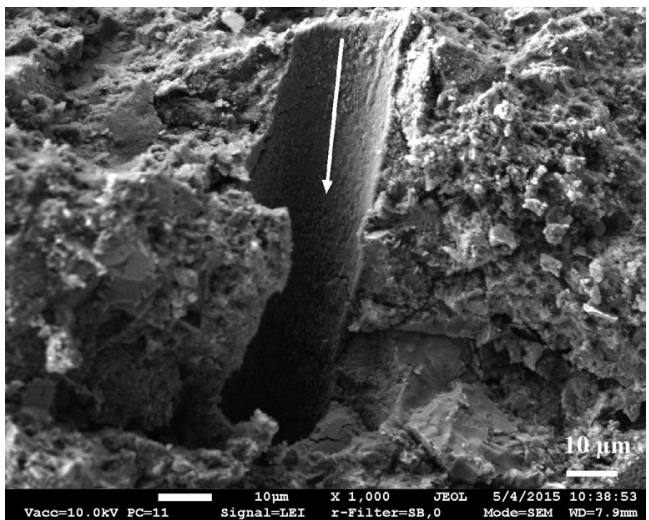

Fig. 3. Burning of additives CF and PP

a)

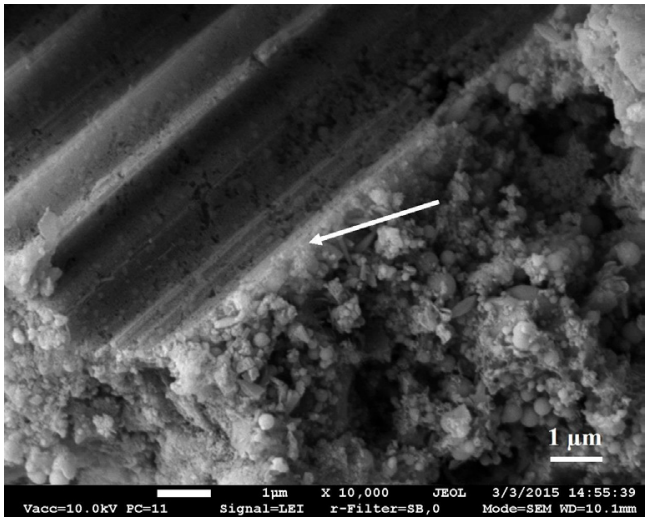

b)

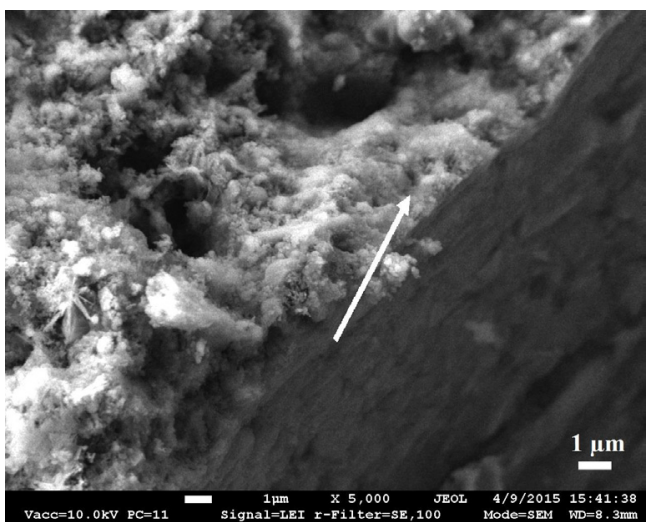

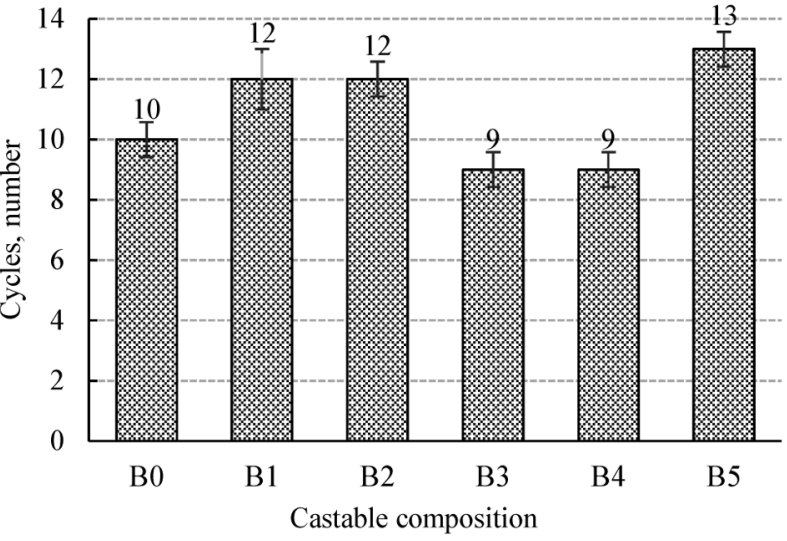

Fig. 5. Thermal shock resistance of refractory castable samples after heating-cooling, the number of cycles

plain the difference in the influence of the additives $\mathrm{CF}$ and PP on the TSR of castable. Perhaps it could be accounted for by the difference in the diameters of fibers and the microchannels that form.

The work of fracture (Table 4) and the values of thermal shock resistance $R_{4}$ and $R_{s t}$ were calculated for three various castable compositions.

Table 4. Work of fracture and TSR of castable samples after heating at a temperature of $950{ }^{\circ} \mathrm{C}$

\begin{tabular}{l|c|c|c}
\hline \multirow{2}{*}{ Properties } & \multicolumn{3}{|c}{ Castable composition } \\
\cline { 2 - 4 } & $\mathrm{B} 0$ & $\mathrm{~B} 1$ & $\mathrm{~B} 3$ \\
\hline$\gamma_{\text {wof }}, \mathrm{J} / \mathrm{m}^{2}$ & 84.1 & 115 & 88 \\
$R_{4}, \mathrm{~m}$ & 0.014 & 0.016 & 0.01 \\
$R_{s t},{ }^{\circ} \mathrm{C} \cdot \mathrm{m}^{1 / 2}$ & 5.44 & 5.82 & 5.6 \\
\hline
\end{tabular}

The results of measurements show that the values of the criteria $R_{4}$ and $R_{s t}$ are higher for castable with CF, which corresponds to the data obtained during thermal cycling of the castable samples (Fig. 5).

There are several different methods for determining $\gamma_{w o f}$. A case of using the dependence force versus deformation' is presented in Figure 6.

Based on the displacement curve of the samples, it is evident that good cohesion and a strong matrix is achieved in the castable with CF. It is believed, that the strong matrix of the castable samples with $\mathrm{CF}$ could be an important characteristic to enhance the thermal stability of this refractory castable.

TSR of castable depends on its physical and mechanical properties, so in striving to estimate the effect of CCS on the TSR of refractory castable, the interrelation between CCS and the density of the castable $(\rho)$ after thermal processing at temperature of $950{ }^{\circ} \mathrm{C}$ was established on the basis of experimental data; the graphical processing of the results is provided in Figure 7.

Fig. 4. Densified castable sample microzones 


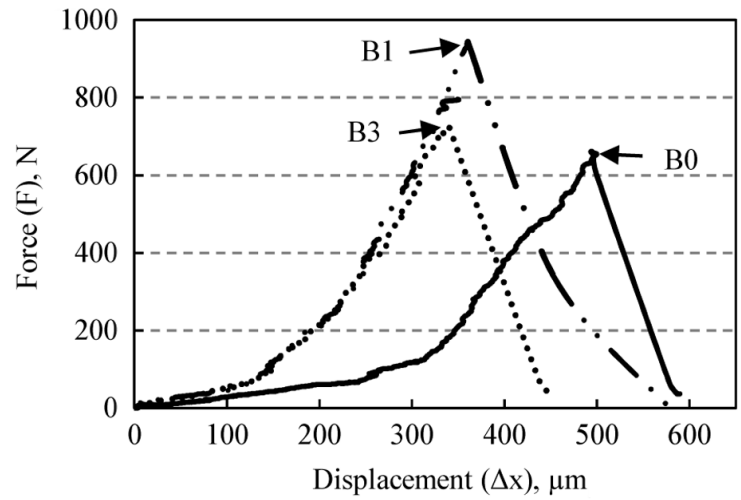

Fig. 6. Experimentally obtained force and strain curves under bend

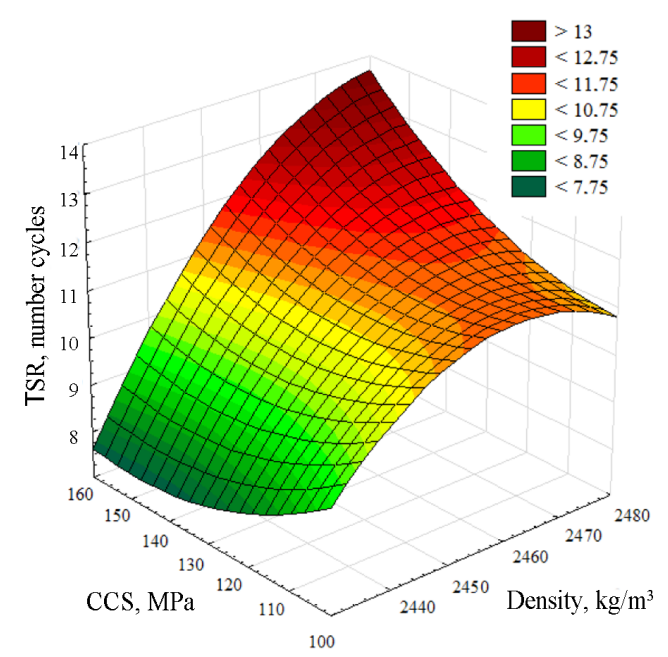

Fig. 7. Dependence of cold crushing strength and density on thermal shock resistance of refractory castable samples after heating at a temperature $950{ }^{\circ} \mathrm{C}$

The obtained effect of CCS (100-160 MPa) and density (2440-2480 kg/m ${ }^{3}$ ) on TSR (Fig. 7) show that on increase of CCS and density in the examined ranges, TSR was increasing as well, so a strong interrelation between the examined indicators exists.

\section{Conclusions}

Combustible additives of carbon and polypropylene fiber contribute to the formation of densified hydrate microzones during hardening in the matrix of medium cement refractory castable with the calcium aluminate clinker filler.

Carbon fiber additive $(0.01 \%$ and $0.02 \%)$ increases the CCS of castable by $\sim 30 \%$ after heating at a temperature of $950{ }^{\circ} \mathrm{C}$, as compared to the CCS of the control specimen of castable. Polypropylene fiber additive $(0.02 \%$ and $0.04 \%)$ increases the CCS of castable by $\sim 22 \%$ and $\sim 35 \%$, respectively, after heating at a temperature of $950^{\circ} \mathrm{C}$, as compared to the CCS of the control specimen of castable. It is noteworthy that in the case where the mix fiber $(\mathrm{CF}+\mathrm{PP})$ additive is used in refractory castable, CCS increases $\sim 30 \%$, as compared to the
CCS of the control specimen of castable. This has a positive effect on the strength characteristics of MCC, when the additives of carbon or polypropylene fiber are used.

It has also been found that the addition of CF improves the TSR of the investigated clinker-based MCC. $\mathrm{CF}$ additive increases the indicator of TSR of castable $\left(950{ }^{\circ} \mathrm{C}\right.$ - cooling in water); it increases by $\sim 20 \%$ from 10 to 12 cycles. In particular, in the case of using the mix fiber $(\mathrm{CF}+\mathrm{PP})$ additive in refractory castable, thermal shock resistance increases $30 \%$, as compared to the CCS of the control specimen of castable. The calculated values of the criteria $R_{4}$ and $R_{s t}$ are higher for castable with $\mathrm{CF}$ as compared to the criteria of the control specimen of castable.

\section{Acknowledgements}

The authors gratefully acknowledge the help of Vilnius Gediminas Technical University Civil Engineering Scientific Research Centre in providing the laboratory equipment, which was used in the present investigation.

\section{References}

Antonovič, V.; Pundienė, I.; Stonys, R.; Čèsnienė, J.; Kerienė, J. 2010. A review of the possible applications of nanotechnology in refractory concrete, Journal of Civil Engineering and Management 16(4): 595-602. https://doi.org/10.3846/jcem.2010.66

ASTM C860-15 Standard Test Method for Determining the Consistency of Refractory Castable Using the Ball-In-Hand Test. ASTM International, 2015.

Ferrari, V. J.; Hanai, J. B.; Souza, R. A. 2013. Flexural strengthening of reinforcement concrete beams using high performance fiber reinforcement cement-based composite (HPFRCC) and carbon fiber reinforced polymers (CFRP), Construction and Building Materials 48: 485-98. https://doi.org/10.1016/j.conbuildmat.2013.07.026

Goberis, S. 2003. Thermal stability of unshaped refractory materials, Refractories and Industrial Ceramics 44: 427-430. https://doi.org/10.1023/B:REFR.0000016783.12573.36

GOST 20910-90:1991 Refractory concretes. Specifications. (in Russian).

Harmuth, H.; Rieder, K.; Krobath, M.; Tschegg, E. 1996. Investigations of the nonlinear fracture behavior of ordinary ceramic refractory materials, Materials Science and Engineering 214: 53-61. https://doi.org/10.1016/0921-5093(96)10221-5

Hasselman, D. P. H. 1963. Elastic energy at fracture and surface energy as design criteria for thermal shock, Journal of the American Ceramic Society 46: 535-540. https://doi.org/10.1111/j.1151-2916.1963.tb14605.x

Hasselman, D. P. H. 1969. Unified theory of thermal shock fracture initiation and crack propagation in brittle ceramics, Journal of the American Ceramic Society 52: 600-604. https://doi.org/10.1111/j.1151-2916.1969.tb15848.x

Innocentini, M. D. M.; Salomao, R.; Ribeiro, C.; Cardoso, F. A.; Pandolfelli, V. C.; Rettore, R. P. 2002. Permeability of fiber- containing refractory castables, American Ceramic Society Bulletin 81: 65-68.

Innocentini, M. D. M.; Cardoso, F. A.; Akyioshi, M. M.; Pandolfelli, V. C. 2003a. Drying stages during the heating of high-alumina, ultra-low-cement refractory castables, Journal of the American Ceramic Society 86: 1146-1148. https://doi.org/10.1111/j.1151-2916.2003.tb03438.x 
Innocentini, M. D. M.; Miranda, M. F. S.; Cardoso, F. A.; Pandolfelli, V. C. 2003b. Vaporization processes and pressure buildup during dewatering of dense refractory castables, Journal of the American Ceramic Society 86: 1500-1503. https://doi.org/10.1111/j.1151-2916.2003.tb03503.x

Kingery, W. D.; Bowen, H. K.; Uhlmann, D. R. 1979. Introduction to ceramics. New York: John Wiley. 1032 p.

Larson, D. R.; Hasselman, D. P. H. 1975. Comparative spalling behaviour of high-alumina refractories subjected to sudden heating or cooling, Transactions and Journal of the British Ceramic Society 74: 59-65.

Lau, A.; Anson, M. 2006. Effect of high temperatures on high performance steel fiber reinforced concrete, Cement and Concrete Research 36: 1698-1707. https://doi.org/10.1016/j.cemconres.2006.03.024

Leung, H. Y.; Balendran, R. V. 2002. Resonant frequency in polypropylene fibre reinforced concrete (PFRC) with pozzolanic materials, Journal of Civil Engineering and Management 8(3): 169-176. https://doi.org/10.1080/13923730.2002.10531273

LST EN ISO 1927-5:2013 Monolithic (unshaped) refractory products - Part 5: Preparation and treatment of test pieces. $23 \mathrm{p}$.

LST EN ISO 1927-6:2013 Monolithic (unshaped) refractory products - Part 6: Measurement of physical properties. $14 \mathrm{p}$.

Mertke, A.; Aneziris, C. G. 2015. The influence of nanoparticles and functional metallic additions on the thermal shock resistance of carbon bonded alumina refractories, Ceramics International 41: 1541-1552.

https://doi.org/10.1016/j.ceramint.2014.09.090

Miyaji, D. Y.; Tonnesen, T.; Rodrigues, J. A. 2014. Fracture energy and thermal shock damage resistance of refractory castables containing eutectic aggregates, Ceramics International 40: 15227-15239.

https://doi.org/10.1016/j.ceramint.2014.06.112

Nili, M.; Afroughsabet, V. 2010. The effect of silica fume and polypropylene fibres on the impact resistance and mechanical properties of concrete, Construction and Building Materials 24: 927-33. https://doi.org/10.1016/j.conbuildmat.2009.11.025

Nishikawa, A. 1984. Technology of monolithic refractories. Japan: Japan by Toppan Printing Company, Ltd. 598 p.

Olivier, V.; Fabien, N. 2014. Industrial simulation for pore pressure prediction during the first drying of refractory castables, in 57th International Colloquium on Refractories, Refractories for metallurgy, (Eurogress), 2014, Aachen, Germany. 5 p.

Pemberton, S. R.; Oberg, E. K.; Daen, J.; Tsarouchas, D.; Markaki, A. E.; Marston, L.; Clyne, T. W. 2011. The fracture energy of metal fibre reinforced ceramic composites (MFCs), Composites Science and Technology 71(3): 266275. https://doi.org/10.1016/j.compscitech.2010.10.011
Peret, C. M.; Pandolfelli, V. C. 2006. Steel fibers and mechanical behavior of refractory castables on drying, American Ceramic Society Bulletin 85: 9401-9407.

Peret, C. M.; Salomao, R.; Zambon, A. M.; Pandolfelli, V. C. 2003. Polymeric fibers and the drying of refractory castables, in $58^{\text {th }}$ Congresso Annual da ABM, 2003, 1715-1724.

Qazi, S.; Michel, L.; Ferrier, E.; Limam, A. 2015. Strut-and-tie model for a reinforced concrete wall strengthened with carbon fibre-reinforced polymers, Composite Structures 128: 8799. https://doi.org/10.1016/j.compstruct.2015.03.024

Ribeiro, S.; Rodrigues, J. A. 2010. The influence of microstructure on the maximum load and fracture energy of refractory castables, Ceramics International 36: 263-274. https://doi.org/10.1016/j.ceramint.2009.07.033

Rodriguez, J. A.; Pandolfelli, V. C.; Rigaud, M. 2002. Elevated temperature thermal parameters for refractories, Proceedings of Interceram 51(5): 322-326.

Rouchka, G.; Vutnau, H. 2010. Refractory materials. Structure, properties, testing. Handbook. Russian translation. Moscow: Intermet Inzhiniring. 392 p. (in Russian).

Sakalauskas, V. 1998. Statistics with Statistica. Vilnius: Margi raštai. 229 p. (in Lithuanian).

Samadi, H.; Fard, F. G. 2003. The effect of fiber addition on low cement castables, in Proceedings of Unitecr'03, 2003, Japan.

Schacht, C. A. 2004. Refractories handbook. USA: CRC Press, Taylor and Francis Group. 520 p. https://doi.org/10.1201/9780203026328

Sika. 2007. Polypropylene fiber for concrete and mortar. Product data sheet. 3 p. [online], [cited 7 January 2016]. Available from Internet: http://norgind.am/storage/files/gallery/ gallery_0528928042_Sika_Fibre.pdf

Tabatabaei, Z. S.; Volz, J. S.; Keener, D. I.; Gliha. B. P. 2014. Comparative impact behavior of four long carbon fibre reinforced concretes, Materials and Design 55: 212-223. https://doi.org/10.1016/j.matdes.2013.09.048

Valivonis, J.; Skuturna, T. 2007. Cracking and strength of reinforced concrete structures in flexure strengthened with carbon fibre laminates, Journal of Civil Engineering and Management 8(4): 169-176.

Wang, N.; Adeli, H. 2014. Sustainable building design, Journal of Civil Engineering and Management 20: 1-10. https://doi.org/10.3846/13923730.2013.871330

Wohrmeyer, C.; Parr, C. 2008. MCC and HCC: deflocculated high-performance castables rich in calcium aluminate binder, in Refractories manual, 57-60.

Wojsa, J.; Wrona, A.; Czechowska, K. 2004. Thermal shock resistance parameters for refractories, in Proceedings of the International Conference "Refractories, Furnaces and Thermal Insulations", 2004, 27-32.

Wojsa, J.; Podwórny, J.; Suwak, R. 2013. Thermal shock resistance of magnesia-chrome refractories-experimental and criterial evaluation, Ceramics International 39: 1-12. https://doi.org/10.1016/j.ceramint.2012.05.102

Valentin ANTONOVIČ. Doctor Chief Researcher, Laboratory of Building Products Technology, Scientific Institute of Thermal Insulation of Vilnius Gediminas Technical University, Lithuania. Research interests: materials science, refractory concretes and their technologies.

Jerzy WITEK. MSc. Eng. Deputy Director for Technology and Application of Refractory Materials of Refractory Materials Division, Institute of Ceramics and Building Materials, Poland. Research interests: refractory materials, ceramic foam filters, thermal shock resistance.

Romualdas MAČIULAITIS. Prof. Doctor Habil of Technological Sciences. Research interests: development of building materials and analysis of their characteristics.

Renata BORIS. Doctor Junior Researcher, Laboratory of Building Products Technology, Scientific Institute of Thermal Insulation of Vilnius Gediminas Technical University, Lithuania. Research interests: materials science, refractory concretes and their application.

Rimvydas STONYS. Doctor Senior Researcher, Laboratory of Building Products Technology, Scientific Institute of Thermal Insulation of Vilnius Gediminas Technical University, Lithuania. Research interests: application of nanotechnologies in cementation's materials, refractory concretes and their application in furnaces. 